\title{
Enhancing student learning: On-line interactive laboratory for modelling of real world control system applications
}

\author{
Joshué Pérez *, Sebastián Dormido**, Ljubo Vlacic *** \\ * Centre of Automation and Robotics (CAR), University Polytechnic of Madrid (UPM) - Spanish National Research Council (CSIC), Madrid, Spain (e-mail: \\ joshue.perez@car.upm-csic.es) \\ **Dep. Informática y Automática Escuela Técnica Superior de Ingeniería Informática, Universidad Nacional de Educación a Distancia, Madrid, Spain,(e- \\ mail:sdormido@dia.uned.es) \\ ***Intelligent Control Systems Laboratory, Griffith University, Brisbane, Australia (e-mai: 1.vlacic@griffith.edu.au).
}

\begin{abstract}
Teaching an introductory course on control systems to undergraduate students often seeks elaborations on real engineering world control system applications to assist students in grasping theoretical concepts. In this paper, the newly developed animated and interactive control systems tutorials are presented. The paper shows that this teaching approach helps students in bridging the gap between the classical control techniques and the real world applications. The course evaluations undertaken since the time of the inclusion of the animated tutorials into the teaching process clearly show the learning improvement gained, reflected in increased average scores, and reduced course fail grade.
\end{abstract}

Keywords: Interactive control system tutorials, Interactive teaching tools, Animation, Distance Education

\section{APPROACHES TO TEACHING THAT INFLUENCE, MOTIVATE AND INSPIRE STUDENTS TO LEARN}

Our teaching methods are often tuned to the needs of a particular course. However, they may change from year to year as different student cohorts often require different teaching strategies towards getting students actively involved in a quality learning process. Consequently, we always try a number of different ways to motivate students towards extending their thinking and exploring the body of knowledge. The ultimate goal is to enhance students' analytical \& critical thinking and problem solving skills.

The cost of building traditional, physical bench top - based, teaching labs is very high. For this reason, a virtual laboratory concept is becoming an increasingly popular teaching \& learning tool since it gives real-world simulated experiences to students in a university environment (Welsh et $\mathrm{al}, 2008)$.

Several new teaching tools have been developed to enhance the teaching process and undergraduate students learning. For example, the University of Almería, in Spain, has developed an Interactive Tool for System Identification Education (ITSIE), which permits to evaluate the main stages of system identification (input signal, model validation, dynamical system, etc) using simulation and real data model. This system was also used as an introduction to system identification courses at Arizona State University (Guzmán et al, 2009).

The North China Electric Power University has had satisfactory results regarding the use of a simulator for simulation of power plant operation (Ma et al, 2008). Firstly, in the simulation environment, students start up the plant, adjust its running parameter and explore plant's possible malfunction on the simulator. Thereafter, they operate the real power system plant with the reduced risk of plant failure since, at that stage, they are already familiar with the concepts associated with the plant control.

Others authors have utilized virtual and remote laboratories for control education to accommodate the needs of the distance education concepts (Dormido et al, 2008, Wang, 2009). These pilot practices, such as the one at the Spanish University of Distance Learning (UNED), demonstrated a template-based approach consistent in the use of Java simulations and LabView to develop a client and a server side. A three-tank and heat flow systems are used to study the control concepts. From the laboratory, students can connect to the real plant from any place at any time.

The University of Newcastle in Australia (Goodwin G.C. 2007) advocates "...the use of physical bench top experiments (such as simple servomechanisms, inverted pendulums etc) as a first step only" as they believe these should be followed by exposing students to real world design via emulation based Virtual Laboratories. They argue that "such emulation experiments can give students an industrially relevant educational experience at relatively low cost". Inspired by that concept, they developed a low cost alternative to physical experiments i.e. an emulation based virtual laboratory for control engineering education (Goodwin G.C. et al, 2011).

This paper presents a set of animated and interactive tutorials that has been developed using MATLAB and Flash macromedia tools which also enabled the design of interactive and an easy-to-use user interface. Numerous control system examples, from the tank level and welding machine control to cooperative robot arms, space telescope and supersonic jet control have been developed, animated and made available to students.

This paper is organized as follows. Section 2, describing some interactive control system application examples, is 
divided into six subsections, each being focused on to the main concept that students must use in control courses. Namely, subsection 2.1 explains the behaviour of first and second order systems, in the context of the time response concept. The subsections 2.2 and 2.3 elaborate on steadystate error and stability of the feedback systems, respectively. The root locus method, drawing attention to cascade control systems, is explained in the subsection 2.4 while the frequency response, using Bode diagram and Nyquist plots, is detailed in subsection 2.5. The last part of section 2 explains how to implement control system design strategies across four applications derived from the real engineering world. Section 3 elaborates on the enhanced students' learning achieved. It also discusses feedback obtained from students including course evaluation score values pointing onto benefits from the use of interactive control system tutorials such as diminishing "Fail" grade in the course over the last three or so years.

\section{DEVELOPMENT OF RESOURCES THAT REFLECT A COMMAND OF THE FIELD: INTERACTIVE CONTROL SYSTEMS TUTORIALS}

The essence and common ground to development of these resources is, in principle, drawn from and in line with scholarly literature on quality teaching (Healey, 2005). Namely, students are asked to embark on inquiry in order to find the required information, critically evaluate and analyse it and finally synthesise findings towards presenting and demonstrating the required knowledge. The ultimate objectives are to facilitate students to effectively: (a) learn the basic body of knowledge; (b) develop analytical and problem-solving skills; and (c) learn to apply developed knowledge to real-life engineering problems.

To achieve these objectives and engage students actively in the learning process and achieve coherence in all aspects of student learning we align curriculum objectives, teaching and learning activities with targeted learning outcomes and related assessment tasks. Such a course curriculum development strategy enables students to connect theory to the real world of engineering design, expose them to the nature of their profession and further their analytical thinking and problem solving skills. We have therefore specifically designed and developed a unique set of interactive and animated control systems tutorials. They are assisting students in going through an inquiry-based learning process that accommodates numerous inquiries they may have.

Through that effort, a set of twenty four control system examples addressing the real world engineering applications have been established. Each example explains control concepts that students had studied in the class lectures, and these are ordered in three main phases: Problem definition, Solution and Animation. The first part describes the problem proposed, variables and concepts used. The second part explains how to solve the problem and to apply the taught concept. It also models and simulates the developed solution in MATLAB modelling environment. The last part is the interactive application, which shows the animation of the problem, evolution of the system outputs, some interactive parameters and it also offers explanations of the concepts used in each case. FLASH multimedia gives interactive features in user-friendly interfaces. Being empowered by computer animation software, the Animated Control Systems Tutorials $^{1}$ assist students to visually relate to problems derived from the real engineering world, understand the solution proposed, interact with its dynamics and, thus, recognise the power of the feedback.

All the animations have real time response, automated update, reset button and also hold mouse pointer to show some parameter of the system (Rise Time, Peak Time, Percent Overshoot and Settling Time). Other tools like slide bar, explanatory report, alarm button and the real time parameter update are also implemented in several examples. Table 1 shows the global information and concepts used in each example.

\subsection{Time Response}

The time response of control systems provides the study of its components: the transient and the steady-state response. In this subsection, all the parameters of the transient response are considered, for both the first and second order systems.

The upper part of the Table 1 shows the features of each example described in the time response subsection such as:

- Boat: ships in turbulent seas incur motion about their roll axis (Nise, 2004).

- Welding Machine: a vision system to measure the geometry of the puddle of melted metal in a welding manufacture (Mutambara, 1999).

- Water tank: water flows into a tank of cross-sectional area and then flows out into atmosphere through a restrictor (Schwarzenbach, 1996).

- Robot painting: a six-axis articulated arm used to paint an automobile (Stanley, 1998).

Each of these examples is depicted on Fig 1.

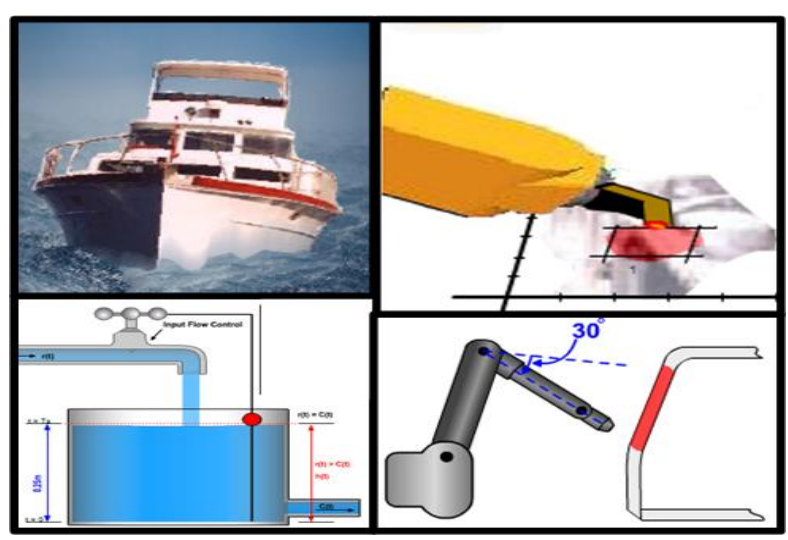

Fig. 1. Time response animations: boat, welding machine, water tank, robot painting.

\footnotetext{
${ }^{1}$ These tutorials and other Control Systems Resources are accessible via www.griffith.edu.au/science/intelligent-control-systems-laboratory
} 
Table 1. Time response, Steady-state error and Stability features (for each example)

\begin{tabular}{|c|c|c|c|}
\hline $\begin{array}{l}\text { Example type: } \\
\text { Input: } \\
\text { Output: }\end{array}$ & $\begin{array}{l}\text { Real } \\
\text { implemen- } \\
\text { tation }\end{array}$ & $\begin{array}{l}\text { Some animation } \\
\text { effects. }\end{array}$ & Concept used \\
\hline Time Response & & & \\
\hline \begin{tabular}{l}
\multicolumn{1}{c}{ Boat } \\
Disturbance-torque \\
roll-angle
\end{tabular} & $\begin{array}{l}\text { IMUs and Fins } \\
\text { actuators }\end{array}$ & $\begin{array}{l}\text { Roll of the ship } \\
\text { caused by sea } \\
\text { waves. }\end{array}$ & $\begin{array}{l}\text { - Natural frequency, Damping ratio, Peak and Rise time. } \\
\text { - Step response for the original system and the analytical } \\
\text { expression (using Laplace transform). }\end{array}$ \\
\hline $\begin{array}{l}\text { Welding Machine } \\
\text { Desired diameter } \\
\text { Puddle diameter }\end{array}$ & $\begin{array}{l}\text { Vision system } \\
\text { and welder tip. }\end{array}$ & $\begin{array}{l}\text { Welder tip over a } \\
\text { metal layer. } \\
\text { Different gains. }\end{array}$ & $\begin{array}{l}\text { - Reduce the order of the system, overshoot and peak } \\
\text { time in second order systems. } \\
\text { - The best gain of the controller for design conditions. }\end{array}$ \\
\hline \begin{tabular}{l|}
\multicolumn{1}{|c|}{ Water tank } \\
Stopcock rate \\
Restrictor at rate \\
\end{tabular} & $\begin{array}{l}\text { Stopcock and } \\
\text { pipe (with } \\
\text { restrictor) }\end{array}$ & $\begin{array}{l}\text { Two interactive } \\
\text { gain values. }\end{array}$ & $\begin{array}{l}\text { - Transfer function using a differential equation } \\
\text { (Laplace). To use initial condition and step input. } \\
\text { - Ts }( \pm 2 \% \text { criterion). Response with different gains. }\end{array}$ \\
\hline $\begin{array}{l}\text { Robot painting. } \\
\text { Desired angle. } \\
\text { Actual angle } \\
\end{array}$ & $\begin{array}{l}\text { Encoders and } \\
\text { AC motor. }\end{array}$ & $\begin{array}{l}\text { It rotates } 30 \text { degrees } \\
\text { the axes. Your arm } \\
\text { control. }\end{array}$ & $\begin{array}{l}\text { - Transfer function for closed loop system. } \\
\text { - Step response for different amplifier gain. } \\
\text { - Critical damped system. }\end{array}$ \\
\hline \multicolumn{4}{|l|}{ Steady-Stage error } \\
\hline \begin{tabular}{l}
\multicolumn{1}{c}{ Space Telescope } \\
Desired Angle \\
Pointing angle \\
\end{tabular} & $\begin{array}{l}\text { Rotation angle } \\
\text { of the space } \\
\text { telescope. }\end{array}$ & $\begin{array}{l}\text { Interactive joystick. } \\
\text { Real time graphic. }\end{array}$ & $\begin{array}{l}\text { - Steady-state error for a step and a ramp input. } \\
\text { - Block diagrams. } \\
\text { - ITAE. }\end{array}$ \\
\hline $\begin{array}{l}\text { DC servo motor } \\
\text { Desired position } \\
\text { Actual position }\end{array}$ & $\begin{array}{l}\text { Encoder, DC } \\
\text { motor }\end{array}$ & $\begin{array}{l}\text { Rolling axle. } \\
\text { Responses with } \\
\text { several gain values. }\end{array}$ & $\begin{array}{l}\text { - The equivalent forward transfer function. System types. } \\
\text { - Position, velocity, acceleration coefficients. }\end{array}$ \\
\hline \begin{tabular}{l|}
\multicolumn{1}{c}{ Elevator } \\
Desired floor \\
Actual Achieved \\
\end{tabular} & $\begin{array}{l}\text { AC Motor. } \\
\text { Absolute } \\
\text { encoder }\end{array}$ & $\begin{array}{l}\text { Five floor building. } \\
\text { Yourself button } \\
\text { option (dif. gains). }\end{array}$ & $\begin{array}{l}\text { - Steady state error for step, ramp and parabolic input. } \\
\text { - Gain }(\mathrm{K}) \text { to yield some error in the steady-state. }\end{array}$ \\
\hline \begin{tabular}{|l|}
\multicolumn{1}{c}{ Mobile robot } \\
Heading angle \\
Actual heading angle \\
\end{tabular} & $\begin{array}{l}\text { Robot arm. } \\
\text { Encoder and } \\
\text { DC motors. }\end{array}$ & $\begin{array}{l}\text { Two interactive } \\
\text { gain values. }\end{array}$ & $\begin{array}{l}\text { - The steady-state error for different inputs. } \\
\text { - Gain value for small steady-state error }(0.1 \%) \text {. }\end{array}$ \\
\hline \multicolumn{4}{|l|}{ Stability } \\
\hline \begin{tabular}{l|}
\multicolumn{1}{c}{ Motorcycle } \\
Vertical angle \\
Actual vertical angle \\
\end{tabular} & $\begin{array}{l}\text { Inclinometer, } \\
\text { (IMU) and } \\
\text { robot steering. }\end{array}$ & $\begin{array}{l}\text { Manual control. } \\
\text { Stable and unstable } \\
\text { control. }\end{array}$ & $\begin{array}{l}\text { - Step response for the dynamics (unstable behaviour). } \\
\text { - Non-unity feedback. Root locus. Disturbance. Pole- } \\
\text { zero cancellation. }\end{array}$ \\
\hline $\begin{array}{l}\text { Electric wheelchairs } \\
\text { Desired Speed } \\
\text { Actual Speed } \\
\end{array}$ & $\begin{array}{l}\text { Speed sensors, } \\
\text { encoders and } \\
\text { DC motor }\end{array}$ & $\begin{array}{l}\text { Lateral and top } \\
\text { view, Joystick and } \\
\text { tacometer }\end{array}$ & $\begin{array}{l}\text { - Limiting gains for a stable system. Settling time. } \\
\text { - The roots of the characteristic equation. }\end{array}$ \\
\hline \begin{tabular}{|c|} 
VTOL Aircraft \\
Desired vertical path \\
Actual Vertical path
\end{tabular} & Height meter & $\begin{array}{l}\text { Vertical takeoff, } \\
\text { aircraft amplitud in } \\
\text { real time. }\end{array}$ & $\begin{array}{l}\text {-Closed loop poles in s-plane. The location according the } \\
\text { gain K. The range of gain K for stable systems. } \\
\text { - Marginal stability. Instability. }\end{array}$ \\
\hline $\begin{array}{l}\text { Continuous caster } \\
\text { Height set point } \\
\text { Height of molten }\end{array}$ & $\begin{array}{l}\text { Slide valve. } \\
\text { Submerged } \\
\text { entry nozzle. }\end{array}$ & $\begin{array}{l}\text { Stable, unstable and } \\
\text { marginally stable } \\
\text { animations. }\end{array}$ & $\begin{array}{l}\text { - Routh-Hurwitz criterion. Critical oscillations. } \\
\text { - Poles for different gains respect to Critical oscillations. } \\
\text {. }\end{array}$ \\
\hline
\end{tabular}

\subsection{Steady-State error}

The steady-state error response explains the system output when the time approaches infinity. The trust of the control system is to reduce the error to the reference point.

Fig. 2 depicts each steady-state error animation as follows:

- Space telescope: the rotation angle is used to control a space telescope (Dorf,2000).

-- DC motor: a DC motor servomechanism with a tachometer, position potentiometer and indicator dial (Goodwin, 2007).
- Elevator: it is a multi-storey building elevator with push button like input of the system (Dorf, 2000).

- Mobile robot: it is used to serve severely disabled people as an assisting device or servant (Dorf, 2000).

\subsection{Stability}

The control system stability is illustrated by the following four examples (Fig. 3):

- Motorbike: this example examines a robot's ability to steer a motorcycle (Dorf, 2000). 


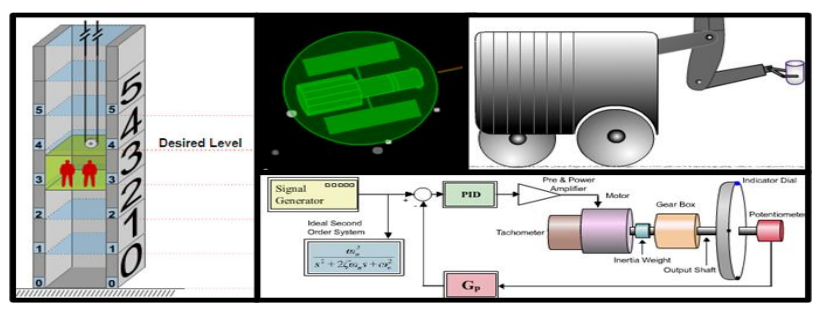

Fig. 2. Steady-Stage error animations: Elevator, space telescope, mobile robot, DC motor.

- Electric wheelchair: it is about a wheelchair that uses velocity sensors mounted in the headgear (Dorf, 2000).

- VTOL aircraft: it is about a vertical takeoff and landing aircraft for small airports (Dorf, 2000).

- Continuous caster: it is about solidifying molten steel into a rectangular bar (Goodwin, 2007).

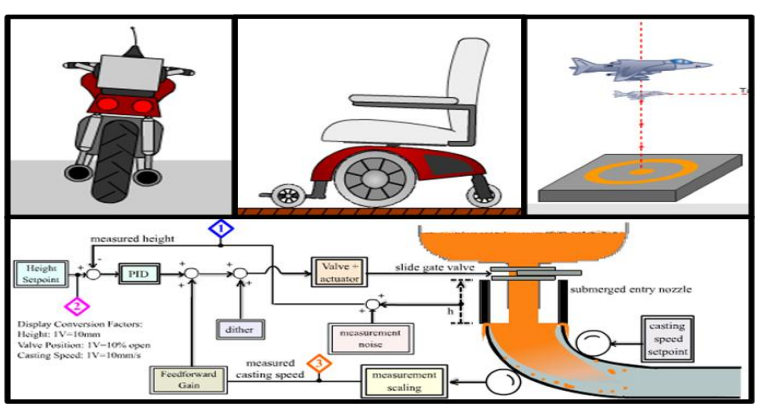

Fig. 3. Stability animations: motorbike, electric wheelchair, VTOL aircraft, continuous caster.

\subsection{Root locus method}

An impact of a gain variation onto the movement of the system poles is discussed in the root loci section.

Fig. 4 shows the examples addressed such as:

- Robot arm: a robot arm actuated at the elbow joint (Dorf, 2000).

- Supersonic passenger jet: it is a futuristic supersonic passenger aircraft that requires good quality handling and comfortable flying conditions (Dorf, 2000).

- Helicopter: a helicopter that utilises an automatic control loop plus a pilot stick control -quite unstable- (Dorf, 2000).

- Elevator: the same elevator used before, but with a faster speed of 25 feet per second (Dorf, 2000).

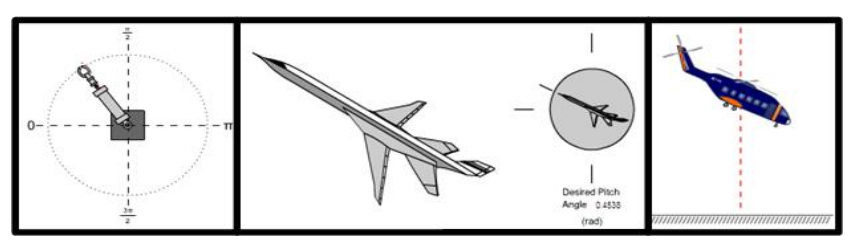

Fig. 4. Root locus animations: Robot arm, Supersonic passenger jet and the helicopter.

\subsection{Frequency Response}

In this subsection, students learn to implement logarithmic and polar plots. Figure 5 shows the following four examples:

- Servo valve and actuator: an electrohydraulic servomechanism using pressure feedback (Dorf, 2000).

- Chemical concentration: a chemical concentration control system that receives a granular feed and delivers composition of the output mixture (Dorf, 2000).

- Tennis player robot: a robot arm with a tennis racket that should attain the best response -and hit the ball-(Dorf, 2000).

- Turbune and generator: a home application that obtains electrical power from a turbine and generator pair (Nise, 2004).

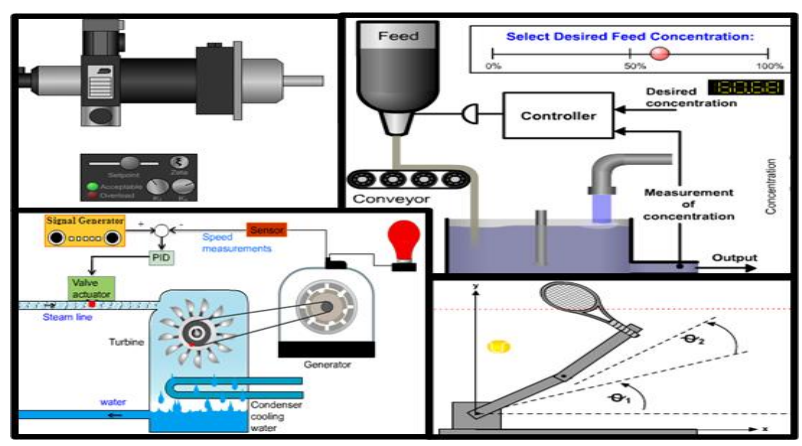

Fig. 5. Frequency response: Servo valve $\&$ actuator, chemical concentration, turbine-generator, tennis player robot.

\subsection{Design}

Design subsection makes an emphasis on complex real world applications. Each example is independent and the students can choose any of the tools explained before, though a standard solution is provided. Fig 6 depicts the examples used, namely:

- Autopilot controlled plane: an autopilot controls the roll angle by adjusting aileron surfaces (Dorf, 2000).

- Vehicle distance: a control task aimed at maintaining the distance between vehicles; this is usually known as an automated highway -plattoning maneuver- (Dorf, 2000).

- Cooperative robot arms: two cooperative robots manipulate a long shaft prior to inserting it into the hole in the block resting on the table (Dorf, 2000).

- Tennis player robot: as in the previous example but improving the transient response of the system (Dorf, 2000).

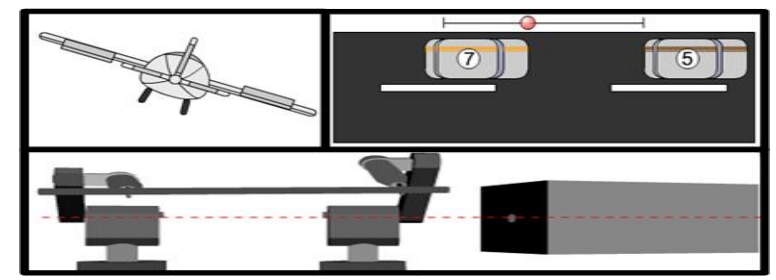

Fig. 6. Design animations: autopilot controlled plane, vehicle distance and cooperative robot arms 
Table 1 (continued)

\begin{tabular}{|c|c|c|c|}
\hline $\begin{array}{l}\text { Example type: } \\
\text { Input: } \\
\text { Output: }\end{array}$ & $\begin{array}{l}\text { Real } \\
\text { implemen- } \\
\text { tation } \\
\end{array}$ & $\begin{array}{l}\text { Some animation } \\
\text { effects }\end{array}$ & Concept used \\
\hline \multicolumn{4}{|l|}{ Root locus } \\
\hline $\begin{array}{l}\text { Robot Arm } \\
\text { Desired position } \\
\text { Actual position } \\
\end{array}$ & $\begin{array}{l}\text { Encoder and } \\
\text { DC motor. }\end{array}$ & $\begin{array}{l}\text { Robot arm uses } \\
\text { three different } \\
\text { gains. }\end{array}$ & $\begin{array}{l}\text { - Gains values for steady-state error equal to zero. } \\
\text { - Tr, Ts ( } 2 \% \text { criterion), Mp for different gains. } \\
\text { - Pole - zero map. }\end{array}$ \\
\hline $\begin{array}{l}\text { Supersonic jet } \\
\text { Desired pitch } \\
\text { Actual pitch } \\
\end{array}$ & $\begin{array}{l}\text { Weight of the } \\
\text { jet and pitch } \\
\text { rate. }\end{array}$ & $\begin{array}{l}\text { Two gains used. } \\
\text { Interactive joystick } \\
\text { and data update. }\end{array}$ & $\begin{array}{l}\text { - Pole-zero map as function of the loop gains. } \\
\text { - Desired characteristics of the dominant roots (Wn, } \zeta \text { ). } \\
\text { - Different conditions (medium or light weight cruise). }\end{array}$ \\
\hline $\begin{array}{l}\text { Helicopter } \\
\text { Stick and pitch } \\
\text { Pitch attitude } \\
\end{array}$ & $\begin{array}{l}\text { Inclinometer, } \\
\text { IMUs and the } \\
\text { pilot stick. }\end{array}$ & $\begin{array}{l}\text { Two different target } \\
\text { levels in the step } \\
\text { input. }\end{array}$ & $\begin{array}{l}\text { - Plot the root locus in an inner closed loop. } \\
\text { - Steady-state error considering disturbances. } \\
\text { - Cascade control. }\end{array}$ \\
\hline \begin{tabular}{|c|}
\multicolumn{1}{c}{ Elevator } \\
Desired floor \\
Actual Achieved \\
\end{tabular} & $\begin{array}{l}\text { AC Motor } \\
\text { Absolute } \\
\text { encoder }\end{array}$ & $\begin{array}{l}\text { Five floor building, } \\
\text { with more speed } \\
\text { than the frst one. }\end{array}$ & $\begin{array}{l}\text { - The root locus. Overshoot and peak time. } \\
\text { - Gains according with damping ratio. }\end{array}$ \\
\hline \multicolumn{4}{|l|}{$\begin{array}{l}\text { Frequency } \\
\text { response }\end{array}$} \\
\hline $\begin{array}{l}\text { Servovalve-actuator } \\
\text { Desired displacement } \\
\text { Actual displacement } \\
\end{array}$ & $\begin{array}{l}\text { Servo valve. } \\
\text { Electric motor }\end{array}$ & $\begin{array}{l}\text { Int. Parameter, } \\
\text { overload signal and } \\
\text { setpoint slide bar }\end{array}$ & $\begin{array}{l}\text { - Bode diagram and phase margin of the system. Phase } \\
\text { and frequency response for different damping ratio }(\zeta) \text {. } \\
\text { - Stable and unstable behaviour. }\end{array}$ \\
\hline $\begin{array}{l}\text { Ch. concentration } \\
\text { Granular feed } \\
\text { output mixture } \\
\end{array}$ & $\begin{array}{l}\text { Concentration } \\
\text { measurement }\end{array}$ & $\begin{array}{l}\text { Automatic update, } \\
\text { and concentration } \\
\text { slide bar. }\end{array}$ & $\begin{array}{l}\text { - Stability of the system using Bode diagram. } \\
\text { - Nyquist criterion. } \\
\text { - Delay time and different gains. }\end{array}$ \\
\hline $\begin{array}{l}\text { Tennis player robot } \\
\text { Desired arm angle } \\
\text { Actual arm angel } \\
\end{array}$ & $\begin{array}{l}\text { Encoder and } \\
\text { DC motor in } \\
\text { the robot. }\end{array}$ & $\begin{array}{l}\text { Three cases with } \\
\text { different gains. }\end{array}$ & $\begin{array}{l}\text { - Plot of the Nyquist diagram. } \\
\text { - Range of gain K for stability using Nyquist diagram. } \\
\text { - Step output responses. }\end{array}$ \\
\hline $\begin{array}{l}\text { Turbine - generator } \\
\text { Dsd. turbine speed } \\
\text { Actual speed }\end{array}$ & $\begin{array}{lr}\text { Steam } & \text { line } \\
\text { valve. } & \text { Speed } \\
\text { sensor. } & \\
\end{array}$ & $\begin{array}{l}\text { Gain values for } \\
\text { stables and } \\
\text { unstables system. }\end{array}$ & $\begin{array}{l}\text { - Speed controls, speed error of a turbine-generator. } \\
\text { - Nyquist diagram, feedback systems. } \\
\text { - Range of gain K for stability. }\end{array}$ \\
\hline \multicolumn{4}{|l|}{ Design } \\
\hline $\begin{array}{l}\text { Autopilot plane } \\
\text { Desired roll angle } \\
\text { Actual roll angle } \\
\end{array}$ & $\begin{array}{l}\text { Aileron. } \\
\text { Hydraulic } \\
\text { actuator }\end{array}$ & $\begin{array}{l}\text { Data and graphic } \\
\text { update. Aileron } \\
\text { moving. }\end{array}$ & $\begin{array}{l}\text { - Reducing block diagram. Step response, overshoot, } \\
\text { setting time }(2 \%) \text { in more slow systems ( } 9 \text { seconds). } \\
\text { - Range of stability. Marginal stability. }\end{array}$ \\
\hline $\begin{array}{l}\text { Vehicle distance } \\
\text { Desired distance } \\
\text { Actual distance }\end{array}$ & $\begin{array}{l}\text { Automated } \\
\text { highway. ACC } \\
\text { or platooning } \\
\end{array}$ & $\begin{array}{l}\text { Data update. } \\
\text { Distance slide bar. }\end{array}$ & $\begin{array}{l}\text { - Steady-state error for a ramp input, overshoot of less } \\
\text { than } 3 \% \text { settling time }(2 \%) \text {. } \\
\text { - Select the parameters of gain }(\mathrm{Ka}) \text { and feedback }(\mathrm{Kt}) \text {. }\end{array}$ \\
\hline $\begin{array}{l}\text { Cooperat. rob-arm } \\
\text { Position of the shaft. } \\
\text { Actual position } \\
\end{array}$ & $\begin{array}{l}\text { Two robots } \\
\text { cooperate to } \\
\text { insert a shaft }\end{array}$ & $\begin{array}{l}\text { One robot arm; } \\
\text { cooperative robots } \\
\text { animation. }\end{array}$ & $\begin{array}{l}\text { - Uncompensated and lead-lag compensated robots. } \\
\text { - Operating point (root locus). } \\
\text { - Steady-State Error for step and ramp input. }\end{array}$ \\
\hline $\begin{array}{l}\text { Tennis player robot } \\
\text { Desired arm angle } \\
\text { Actual arm angel }\end{array}$ & $\begin{array}{l}\text { Encoder and } \\
\text { DC motor in } \\
\text { the robot. }\end{array}$ & $\begin{array}{l}\text { Lead compensation } \\
\text { control animation. }\end{array}$ & $\begin{array}{l}\text { - Improving the transient response of the system. } \\
\text { - Design a Lead compensator. Compensated and } \\
\text { uncompensated response for the step inputs. }\end{array}$ \\
\hline
\end{tabular}

\section{THE ENHANCED STUDENTS' LEARNING ACHIEVED}

The obtained learning outcomes have been fruitful, beneficial and encouraging. Students responded with great enthusiasm, an increased interest towards control systems discipline and perceived a higher degree of industrial relevance of the Control Systems Theory. Furthermore, this has encouraged students to voice their opinion and share it with their peers. In return, such a learning climate has created a high level of student satisfaction and enhanced learning. Even so, we then decided to also introduce virtual laboratory-based experiments, as those developed by the University of Newcastle, Australia (G.C. Goodwin et al., 2011). Both resources, the animated control systems tutorials - introduced from 2005, as well as the virtual control systems design laboratory - introduced from 2009, contributed towards diminishing the course "Fail" grade: a) from approx $12.5 \%$ (in 2002) to zero (in 2009 and 2010) for the Introductory Control Systems course - 3304ENG; and b) from 9\% (in 2005) to zero (in 2007, 2008, 2009 and 2010) for the Digital Control Systems Engineering course - 4308ENG. For details, see Figure 7. 


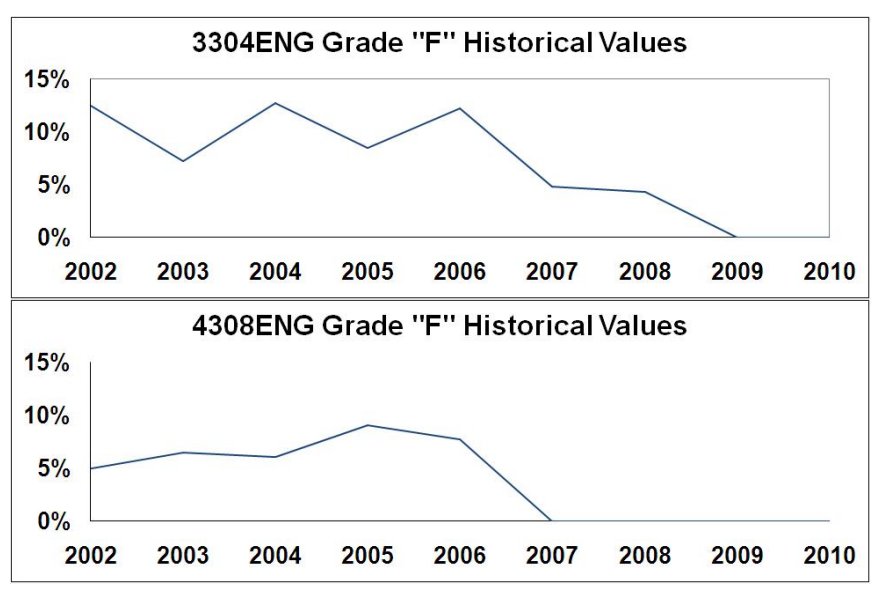

Fig 7. Grade "F" Historical values

The continuously undertaken annual course evaluations clearly show the improvement attained with this method reflected in increased average scores since 2005 when we commenced the use of the animated and interactive control systems tutorials in our classroom teaching. The historical values shown below are calculated by averaging the mean values, obtained for the following two questions: Student Evaluation of Course question SEC Q10: "Overall, how effective was this course in helping you to learn?" and Student Evaluation of Teaching question SET Q10: "Overall, how effective was this lecturer/tutor in helping you to learn? "A class size ranged from approx 30 to approx 70 students/year over the past fifteen years.

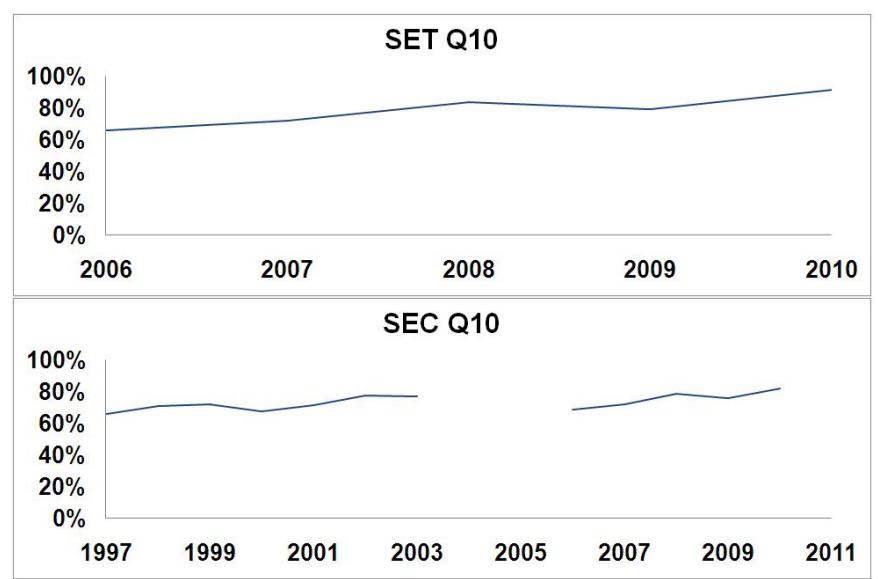

Fig 8. Course evaluation historical values

\section{FUTURE WORK}

The presented interactive control systems tutorials have been developed in conjunction with the Control Resources initiative of the International Federation of Automatic Control (IFAC). That initiative, being developed under the concept of creating a one-stop control systems theory \& engineering's repository, is also providing information of relevance to: (i) history of control; (ii) control theory timeline data; (iii) control engineering textbook titles; (iv) control systems applications; and (v) history of IFAC. The Control Resources initiative is still in progress and will undergo further development, including broadening its current scope and the information presented.

\section{REFERENCES}

Dorf, R.C. and Bishop, R.H.(2000) Modern Control Systems, Ninth edition, Addison Wesley.

Dormido, S. et al. (2008) Developing and Implementing Virtual and Remote Labs for Control Education: The UNED pilot experience. 17th IFAC World Congress. Seoul, Korea. Pages 8159-8164.

Goodwin, G.C., (2007) Virtual Laboratories for Control System Design Laboratory Book: Continuous Caster Package Student Manual, Newcastle Innovation Limited.

Goodwin, G.C. et al. (2011): "Emulation-based Virtual Laboratories: A low-cost alternative to physical Experiments in Control Engineering Education". The IEEE - Transactions on Education, Vol. 54, Issue 1, pp.48-55

Guzmán, J.L. et al. (2009). Teaching System Identification Through Interactivity. The 8th IFAC Symposium on Advances in Control Education (ACE 2009), Kumamoto, Japan.

Healey, M. (2005). "Linking research and teaching exploring disciplinary spaces and the role of inquiry-based learning", In Barnett, R (Ed) (2005): Reshaping the University: New Relationships between Research, Scholarship and Teaching, McGraw Hill/Open University Press pp.67-78

Ma, Y., Ma, J., Li, J. and Ran, P.(2008). The Simulator Operation Instruction System for Simulation Practice of Power Plant Operation. 7th Intl. Conf. on Sys. Simulation and Scientific Computing. pp. 359-362.

Mutambara, Arthur G.O., (1999) Design and Analysis of Control Systems, pp. 338, CRC Press.

Nise, Norman S, (2004) Control Systems Engineering. p.230. Fourth edition, John Wiley \& Sons Inc.

Schwarzenbach, J.(1996) Essentials of Control. pp18. Longman Pub. Group.

Stanley M. Shiners, (1998) Modern Control System Theory and Design, 2nd edition; pp. 266-267,

Wang, T.,(2009). Educational Benefits of Multimedia Skills Training. International Association of Computer Science and Information Technology - Spring Conference. pp. 25-29.

Welsh, J.S. et al. (2008) Simulated versus Hardware Laboratories for Control Education: A Critical Appraisal. 17th IFAC World Congress. Seoul, Korea. pp. 81298134. 